\title{
SRM Section News
}

\section{SRM Wildlife Habitat Committee 2005-2006 Annual Report}

SRM's Wildlife Habitat Committee (WHC) is composed of individuals dedicated to improving our understanding of the science and management of rangeland wildlife and their habitat. Our major functions are to provide information to SRM and others on wildlife ecology and management, foster relationships between SRM and other wildlife groups, and to provide input on pending legislation that may affect rangeland wildlife. The WHC meets each year at the SRM Annual Meeting, and membership is open to all SRM members who attend or contact the committee chair. This report highlights some of the contributions we have made over the past year.

The WHC was instrumental in working with 5 other professional societies to develop the Scientific Societies' Statement on the Endangered Species Act. Because of Congressional scrutiny of the Endangered Species Act (ESA) of 1973, SRM joined the American Fisheries Society, the Ecological Society of America, the Entomological Society of America, the Society for Conservation Biology, and The Wildlife Society in an effort to produce a joint statement on science-related issues in the ESA reauthorization. Our common goal was to improve the science and effectiveness of recovering rare and declining species and their habitats. We focused solely on the issues that we thought our expertise as scientists and experience in helping to implement the ESA was most relevant. Throughout the effort, we maintained a focus on the science-related issues in order to preserve the scientific integrity of our societies and thereby increase the credibility of our statement. With the approval of the Board of Directors, SRM became an official signatory of the joint statement in February 2006. The statement was developed after the US House of Representatives passed its version of the ESA reauthorization (H.R. 3824, The Threatened and Endangered Species Recovery Act).
However, we were able to provide our statement to the US Senate before it considered the issue.

The WHC regularly develops special symposia for SRM Meetings to explore important rangeland wildlife topics. Three symposia were developed and presented at the SRM Annual Meeting in Vancouver, British Columbia. These half-day sessions covered the following topics: 1) Wildlife Habitat Analysis of the Future: Examining Multiple Scales using Geospatial Technology, 2) Application of the Collaborative Resources Stewardship Process, and 3) Grazing, Riparian, ColdWater Fish: Is Beneficial Coexistence Possible? We plan on organizing special symposia for the Annual Meeting in Reno, Nevada, and welcome your participation.

Throughout the year, the WHC is asked to review and comment on a wide variety of efforts and publications. Some of the issues we provided input on included the Sustainable Rangelands Roundtable Charter and Core Indicators, a Canadian proposal to develop best management practices for at-risk species, and revisions to the SRM Position, Policy, and Resolution Statements. We publish committee business updates, along with articles on emerging wildlife habitat issues, in our regular newsletters. Three newsletters were produced and distributed over the past year. Newsletters can be found on-line at the SRM home page (www.rangelands.org) by navigating to the Wildlife Habitat Committee page.

The WHC Officers for 2006 are Roy Roath (Chair), Ted Toombs (Chair-Elect), and Lance Vermeire (Communications Director). Steve Peterson was selected as Chair for 2008. A special thanks to the members of the WHC for their commitment and hard work in 2005.

Prepared by Jeremy Maestas (2005 Chair); Jeremy.maestas@ ut.usda.gov. 